\title{
Coronary heart disease incidence in northern and southern European populations: a reanalysis of the seven countries study for a European coronary risk chart
}

\author{
A Menotti, M Lanti, P E Puddu, D Kromhout
}

\begin{abstract}
Objective-A systematic reanalysis of 10 year coronary heart disease incidence data from the northern and the southern European cohorts of the seven countries study, to contribute indirectly to the production of a European coronary risk chart.

Design and setting-Men aged 40-59 years at entry were studied in three northern European cohorts based in Finland and Netherlands $(n=2213)$; and in 10 southern European cohorts based in Italy, former Yugoslavia, and Greece $(n=5897)$. Multiple logistic models for the prediction of coronary deaths, coronary incidence (hard criteria), and coronary incidence (any criterion) were solved for the two geographical groups and their pool. Risk factors fed into the models were age, systolic blood pressure, serum total cholesterol, and cigarette smoking.

Results-10 year coronary heart disease mortality and incidence were higher in northern than in southern Europe, with ratios around 2.65. Ratios among the three coronary heart disease manifestations were identical in the two cultural groupings. Coefficients of the multiple logistic models were similar and not significantly different between the two groupings. When applying the coefficients back to the same or the opposite population, the relative risk was large and similar in the different cultures. Relative risk was larger for more severe coronary heart disease manifestations. The absolute risk was overestimated when applying the northern European model to southern European populations and vice versa, with ratios of about 1.5 and 0.5 , respectively. Coronary risk charts created to reproduce the shape of those incorporated in recent European guidelines confirmed the excess of absolute risk in the northern compared with the southern European cohorts, all else being equal.

Conclusions-In theory, a more appropriate European coronary risk chart could be produced by adopting coefficients to correct for different background incidence rates in different cultures. Other coefficients could appropriately be used to transform mortality risk into incidence risk.

(Heart 2000;84:238-244)
\end{abstract}

Keywords: coronary heart disease; risk factors; risk estimate

Division of

Epidemiology,

University of

Minnesota,

Minneapolis,

Minnesota, USA

A Menotti

Association for Cardiac Research

(Associazione per la

Ricerca Cardiologica),

Via Adda 87, Rome

00198, Italy

M Lanti

P E Puddu

Division of Public

Health Research,

National Institute for

Public Health and

Environment,

Bilthoven, Netherlands

D Kromhout

Correspondence to:

Dr Lanti

email: mplanti@tin.it

Accepted 10 May 2000
There is increasing interest in coronary risk functions for predicting coronary events, and coronary risk charts are now incorporated into guidelines for the prevention of coronary heart disease and for treating risk factors. In Europe this effort has so far not been very successful ${ }^{12}$ because large differences in absolute risk are found among the different countries and few studies provide information on non-fatal events. $^{3}$ As a result, the European guidelines have employed a coronary risk chart derived from the Framingham study. ${ }^{4}$ However, it is known that the Framingham risk functions overestimate coronary risk when applied to a southern European population. ${ }^{5}$

A European research group is now trying to create a more relevant coronary risk chart by pooling recent longitudinal studies from various European countries (the SCORE (systemic coronary risk evaluation) project). The expectation is, however, that a comprehensive risk function may not be valuable for all European populations and that the estimate might be confined to coronary deaths, as few studies provide non-fatal incidence data.

This analysis represents a systematic reappraisal of data from the seven countries study of cardiovascular diseases which enrolled, in the early 1960s, a total of 13 cohorts in northern and southern European countries. ${ }^{6-8}$

The objectives of this analysis were as follows:

- to produce risk functions for the prediction of coronary events using a minimum number of risk factors corresponding to those commonly employed in the current coronary risk charts, and using incidence data as the end point;

- to compare the risk functions generated from northern and southern European countries to identify differences and similarities;

- to produce an experimental coronary risk chart that could contribute, at least theoretically, to the production of useful European charts.

\section{Methods}

The analysis was conducted on the European cohorts of the seven countries study, made up of men aged 40-59 years, located in Finland (cohorts from east and west Finland), Netherlands (Zutphen cohort), Italy (cohorts from Crevalcore, Montegiorgio, and Rome railroad employees), Croatia-former Yugoslavia 
(cohorts from Dalmatia and Slavonia), Serbiaformer Yugoslavia (cohorts from Velika Krsna, Zrenjainin, and Belgrade), and Greece (cohorts from Crete and Corfu).

The cohorts from Finland and the Netherlands represented northern Europe; the cohorts from Italy, Croatia, Serbia, and Greece represented southern Europe.

All cohorts were located in rural areas except Zutphen (a small commercial town in the Netherlands), Rome (railroad employees in defined occupations), Zrenjanin (an agroindustrial cooperative in Serbia), and Belgrade (university professors in Belgrade).

The entry examination was held between 1958 and 1964 and included measurement of risk factors, other personal characteristics, and clinical data, with participation rates greater than $90 \%$. Subsequent re-examinations were held after five and 10 years, again with high participation rates. ${ }^{78}$

Information on mortality was collected periodically in the single areas. The collection of data on vital status and causes of death was complete for the 10 years follow up considered here, and no subjects were lost. Causes of death were allocated by reviewing and combining information from death certificates, hospital and medical records, and interviews with physicians and relatives of the deceased and any other witness of the fatal event. Causes of death were determined by a single reviewer (AM), employing the eighth revision of the WHO International Classification of Diseases ${ }^{9}$ and following defined criteria. In the presence of multiple causes, a hierarchical preference was adopted, with violence, cancer in advanced stages, coronary heart disease, and stroke in that order.

Information on non-fatal events was collected at the time of the re-examination at year 5 and year 10 of follow up, based on clinical questionnaires, physical examination, ECG recordings, and review of personal clinical records.

The risk factors considered for this analysis were those measured at entry examination, as follows:

- age, in years, approximated to the nearest birthday;

- systolic blood pressure in $\mathrm{mm} \mathrm{Hg}$, as an average of two measurements taken with the subjects in the supine position, one minute apart, by trained physicians, following the rules given in the WHO Cardiovascular survey methods manual ${ }^{10}$;

- total serum cholesterol in $\mathrm{mmol} / \mathrm{l}$ measured on casual blood samples, using the methods of Anderson and Keys ${ }^{11}$;

- smoking habits, derived from a questionnaire and simplified as current smokers and current non-smokers (codes 1 and 0 ).

Incident coronary events were those occurring in 10 years of follow up and were as follows:

- coronary heart disease deaths (CHDD), corresponding to sudden and non-sudden coronary deaths, and to fatal acute or chronic myocardial infarction;

- coronary heart disease hard cases $(\mathrm{CHDH})$, which included the above coronary heart disease deaths plus cases of non-fatal definite myocardial infarction, defined by the rules of the study $^{7}$;

- coronary heart disease any cases (CHDA), which included the above $\mathrm{CHDH}$ plus cases of non-fatal possible myocardial infarction and definite angina pectoris, as defined by the rules of the study. ${ }^{78}$

Fatal cases were subjects who, independently of the sequence in the natural history of the disease, died within the period of follow up. Non-fatal cases were subjects who, independently of the time of onset of the disease, were still alive at the end of the follow up period. Each individual was classified by the most severe manifestation occurring during the 10 years of follow up. Incidence was computed after exclusion of cases with any coronary heart disease manifestation present at entry.

Baseline data were collected in the late 1950s and early 1960s, before the era of the Helsinki Declaration. Subsequently, informed consent was obtained orally with a view to collecting follow up data.

\section{DATA ANALYSIS}

The predictive model employed here was the multiple logistic function. This was an enforced choice as only five of the 13 cohorts have dates for the occurrence of non-fatal events.

Risk functions were separately produced for the northern European cohorts, the southern European cohorts, and all European cohorts pooled, and separately for $\mathrm{CHDD}, \mathrm{CHDH}$, and CHDA events. The solutions on the pooled European cohorts included a dummy variable identifying the geographical location (northern Europe taken as reference).

Men with manifestations of coronary heart disease at entry were excluded from the denominator, as well as those who, over the 10 year follow up, died from a cause other than coronary heart disease and those with missing data. This choice was taken to avoid possible distortions in the coefficients of those factors that are strongly associated with deaths other than from coronary heart disease.

We compared coefficients from different geographical groups by $t$ tests, assessing the same risk factors within the same end points. For each end point, the coefficients and the constant were applied back to the individuals of the same and the opposite population. The coefficients and the constant of the whole European pool were applied back to their own data only.

The estimated ranked probabilities were divided in quintile classes and the observed cases were distributed in those classes, allowing us to compute the relative risk between quintile 5 and quintile 1 of the estimated risk. The sum of the individual estimated probabilities gave the number of expected cases as a whole and within each quintile. The distributions of expected and observed cases in quintile classes were compared.

Using the coefficients and the constant of each solution, charts were computed where probabilities were estimated for arbitrary combinations of age, systolic blood pressure, serum cholesterol, and smoking habits. A colour chart including all the information from both areas 
Table 1 Incidence of coronary heart disease (CHD) manifestations in subjects used in the analysis

\begin{tabular}{|c|c|c|c|c|c|}
\hline \multirow[b]{2}{*}{ CHD events } & \multicolumn{2}{|c|}{ Northern Europe $(n=2213)$} & \multicolumn{2}{|c|}{ Southern Europe $(n=5897)$} & \multirow[b]{2}{*}{$\begin{array}{l}\text { Ratios } \\
\text { north/south }\end{array}$} \\
\hline & Events & $\begin{array}{l}\text { Rate } / 1000 \text { in } \\
10 \text { years }\end{array}$ & Events & $\begin{array}{l}\text { Rate } 1000 \text { in } \\
10 \text { years }\end{array}$ & \\
\hline CHDD & 114 & 51 & 113 & 19 & 2.68 \\
\hline $\mathrm{CHDH}$ & 190 & 86 & 192 & 32 & 2.69 \\
\hline CHDA & 391 & 177 & 395 & 67 & 2.64 \\
\hline \multicolumn{6}{|l|}{ Ratios } \\
\hline $\mathrm{CHDD} / \mathrm{CHDH}$ & - & 0.59 & - & 0.59 & - \\
\hline CHDD/CHDA & - & 0.28 & - & 0.28 & - \\
\hline $\mathrm{CHDH} / \mathrm{CHDA}$ & - & 0.49 & - & 0.48 & - \\
\hline
\end{tabular}

Subjects who died from non-coronary events are excluded.

CHDA, CHD any criterion; $\mathrm{CHDD}, \mathrm{CHD}$ deaths; $\mathrm{CHDH}, \mathrm{CHD}$ hard criteria.

and using classes of risk instead of single risk values was also produced, reflecting the style employed in the European guidelines. ${ }^{12}$

\section{Results}

INCIDENCE RATES AND MULTIVARIATE MODELS In all, 2555 men were enrolled in northern Europe and 6625 in southern Europe. Table 1 gives the number of men used in this analysis and crude incidence rates for the three coronary end points in 10 years, in the men who were free of coronary heart disease manifestations at entry and with no missing data for multivariate analysis. Incidence was systematically higher in northern than in southern Europe for each end point, with ratios around 2.65 between the two cultures. On the other hand the ratios between each pair of coronary heart disease manifestations within each culture were practically the same.

The solutions of the multiple logistic function are given in table 2. For both areas and their pool, for the three end points, and for each risk factor, the coefficients were significant $(p<0.05)$ except for smoking habits in southern Europe in the model dealing with CHDA.

Although the magnitude of the coefficients was generally larger in the northern European group, the comparison made by $t$ test on all pairs of coefficients showed no significant difference between northern Europe and southern Europe. Despite large differences, the constants were also not significantly different between northern and southern Europe.

\section{CROSSOVER OF MULTIVARIATE MODELS WITHIN} THE SAME POPULATION

These data are shown in table 3. In this case, owing to the mathematical properties of the multiple logistic function, the number of observed cases corresponds to the number of expected cases. The distribution of the observed cases in quintile classes of estimated risk shows high levels of relative risk. They are higher for CHDD, intermediate for $\mathrm{CHDH}$, and lower but still important for CHDA.

In each quintile class of estimated risk, the observed cases were also distributed for the two end points not generating the specific solution, but owing to lack of space they are not reported here in detail. For example, in the quintile classes of the estimated risk for CHDD, cases were also distributed for $\mathrm{CHDH}$ and CHDA (and so forth for the other solutions), in order to investigate the extent to which models derived from one end point are able to discriminate different types of events. This approach also showed high levels of relative risk for cases belonging to a different end point and predicted by a different model.

In general the relative risks were particularly increased in the model of the pooled northern and southern European cohorts, probably because of the larger size of the sample.

Table 2 Multiple logistic models for three end points, two areas, and their pool

\begin{tabular}{|c|c|c|c|c|c|c|c|c|}
\hline & & & Constant & Age & $\begin{array}{l}\text { Systolic blood } \\
\text { pressure }\end{array}$ & Cholesterol & Smoker & $\begin{array}{l}\text { Dummy for } \\
\text { south Europe }\end{array}$ \\
\hline CHDD & $\mathrm{NE}$ & $\begin{array}{l}\text { Coefficient } \\
\text { Standard error } \\
t \text { value }\end{array}$ & $\begin{array}{l}-13.03 \\
1.29 \\
-10.1\end{array}$ & $\begin{array}{l}0.0702 \\
0.0192 \\
3.66\end{array}$ & $\begin{array}{l}0.0266 \\
0.0042 \\
6.28\end{array}$ & $\begin{array}{l}0.3248 \\
0.0696 \\
4.67\end{array}$ & $\begin{array}{l}0.5971 \\
0.2280 \\
2.62\end{array}$ & $\begin{array}{l}- \\
- \\
-\end{array}$ \\
\hline CHDD & SE & $\begin{array}{l}\text { Coefficient } \\
\text { Standard error } \\
t \text { value }\end{array}$ & $\begin{array}{l}-11.74 \\
1.13 \\
-10.4\end{array}$ & $\begin{array}{l}0.0634 \\
0.0191 \\
3.32\end{array}$ & $\begin{array}{l}0.0207 \\
0.0040 \\
5.11\end{array}$ & $\begin{array}{l}0.2591 \\
0.0812 \\
3.19\end{array}$ & $\begin{array}{l}0.4622 \\
0.2020 \\
2.29\end{array}$ & $\begin{array}{l}- \\
- \\
-\end{array}$ \\
\hline CHDD & Pool & $\begin{array}{l}\text { Coefficient } \\
\text { Standard error } \\
t \text { value }\end{array}$ & $\begin{array}{l}-12.02 \\
0.87 \\
-13.8\end{array}$ & $\begin{array}{l}0.0661 \\
0.0135 \\
4.90\end{array}$ & $\begin{array}{l}0.0232 \\
0.0029 \\
8.04\end{array}$ & $\begin{array}{l}0.2900 \\
0.0503 \\
5.76\end{array}$ & $\begin{array}{l}0.5173 \\
0.1510 \\
3.44\end{array}$ & $\begin{array}{l}-0.4632 \\
0.1570 \\
-2.96\end{array}$ \\
\hline $\mathrm{CHDH}$ & $\mathrm{NE}$ & $\begin{array}{l}\text { Coefficient } \\
\text { Standard error } \\
t \text { value }\end{array}$ & $\begin{array}{l}-11.48 \\
1.02 \\
-11.3\end{array}$ & $\begin{array}{l}0.0740 \\
0.0151 \\
4.91\end{array}$ & $\begin{array}{l}0.0228 \\
0.0352 \\
6.47\end{array}$ & $\begin{array}{l}0.2552 \\
0.0580 \\
4.40\end{array}$ & $\begin{array}{l}0.4497 \\
0.1750 \\
2.57\end{array}$ & $\begin{array}{l}\overline{-} \\
\overline{-}\end{array}$ \\
\hline $\mathrm{CHDH}$ & SE & $\begin{array}{l}\text { Coefficient } \\
\text { Standard error } \\
t \text { value }\end{array}$ & $\begin{array}{l}-9.99 \\
0.87 \\
-11.5\end{array}$ & $\begin{array}{l}0.0576 \\
0.0146 \\
3.95\end{array}$ & $\begin{array}{l}0.0149 \\
0.0034 \\
4.44\end{array}$ & $\begin{array}{l}0.2475 \\
0.0619 \\
4.00\end{array}$ & $\begin{array}{l}0.4913 \\
0.1570 \\
3.12\end{array}$ & $\begin{array}{l}- \\
- \\
-\end{array}$ \\
\hline $\mathrm{CHDH}$ & Pool & $\begin{array}{l}\text { Coefficient } \\
\text { Standard error } \\
t \text { value }\end{array}$ & $\begin{array}{l}-10.32 \\
0.67 \\
-15.3\end{array}$ & $\begin{array}{l}0.0652 \\
0.0104 \\
6.24\end{array}$ & $\begin{array}{l}0.0185 \\
0.0024 \\
7.72\end{array}$ & $\begin{array}{l}0.2436 \\
0.0425 \\
5.73\end{array}$ & $\begin{array}{l}0.4666 \\
0.1170 \\
4.00\end{array}$ & $\begin{array}{l}-0.5610 \\
0.1230 \\
-4.58\end{array}$ \\
\hline CHDA & $\mathrm{NE}$ & $\begin{array}{l}\text { Coefficient } \\
\text { Standard error } \\
t \text { value }\end{array}$ & $\begin{array}{l}-8.51 \\
0.73 \\
-11.7\end{array}$ & $\begin{array}{l}0.0520 \\
0.0108 \\
4.81\end{array}$ & $\begin{array}{l}0.0173 \\
0.0028 \\
6.21\end{array}$ & $\begin{array}{l}0.2475 \\
0.0425 \\
5.82\end{array}$ & $\begin{array}{l}0.2749 \\
0.1250 \\
2.20\end{array}$ & $\begin{array}{l}- \\
- \\
-\end{array}$ \\
\hline CHDA & SE & $\begin{array}{l}\text { Coefficient } \\
\text { Standard error } \\
t \text { value }\end{array}$ & $\begin{array}{l}-8.23 \\
0.61 \\
-13.5\end{array}$ & $\begin{array}{l}0.0424 \\
0.0102 \\
4.14\end{array}$ & $\begin{array}{l}0.0181 \\
0.0024 \\
7.48\end{array}$ & $\begin{array}{l}0.1547 \\
0.0464 \\
3.33\end{array}$ & $\begin{array}{l}0.1775 \\
0.1080 \\
1.64\end{array}$ & $\begin{array}{l}- \\
- \\
-\end{array}$ \\
\hline CHDA & Pool & $\begin{array}{l}\text { Coefficient } \\
\text { Standard error } \\
t \text { value }\end{array}$ & $\begin{array}{l}-7.93 \\
0.48 \\
-16.6\end{array}$ & $\begin{array}{l}0.0465 \\
0.0074 \\
6.27\end{array}$ & $\begin{array}{l}0.0176 \\
0.0018 \\
9.63\end{array}$ & $\begin{array}{l}0.2449 \\
0.0309 \\
7.92\end{array}$ & $\begin{array}{l}0.2202 \\
0.0815 \\
2.70\end{array}$ & $\begin{array}{l}-0.7197 \\
0.0888 \\
-8.11\end{array}$ \\
\hline
\end{tabular}

Age in years; systolic blood pressure in $\mathrm{mm} \mathrm{Hg}$; serum cholesterol in $\mathrm{mmol} / \mathrm{l}$; smoker: yes/no; dummy identifies southern Europe (northern Europe as reference).

NE, northern Europe; Pool, northern + southern Europe; SE, southern Europe; see table 1 for key to other abbreviations. 
Table 3 Back application of coefficients for coronary heart disease deaths to the same population

\begin{tabular}{|c|c|c|c|c|c|c|c|c|c|}
\hline \multirow[b]{2}{*}{ CHD type } & \multirow[b]{2}{*}{ Area } & & \multirow[b]{2}{*}{ Total cases } & \multicolumn{5}{|c|}{ Quintile class } & \multirow[b]{2}{*}{$R R 5 / 1$} \\
\hline & & & & 1 & 2 & 3 & 4 & 5 & \\
\hline CHDD & $\mathrm{NE}$ & $\begin{array}{l}\text { Observed } \\
\text { Expected } \\
\text { E/O ratio }\end{array}$ & $\begin{array}{l}114 \\
114.3 \\
1.00\end{array}$ & $\begin{array}{l}5 \\
5.7\end{array}$ & $\begin{array}{l}5 \\
10.7\end{array}$ & $\begin{array}{l}16 \\
16.2\end{array}$ & $\begin{array}{l}34 \\
24.7\end{array}$ & $\begin{array}{l}54 \\
57.0\end{array}$ & $\begin{array}{l}10.8 \\
10.0\end{array}$ \\
\hline CHDD & SE & $\begin{array}{l}\text { Observed } \\
\text { Expected } \\
\text { E/O ratio }\end{array}$ & $\begin{array}{l}113 \\
113.7 \\
1.00\end{array}$ & $\begin{array}{l}6 \\
7.0\end{array}$ & $\begin{array}{l}14 \\
12.1\end{array}$ & $\begin{array}{l}21 \\
17.3\end{array}$ & $\begin{array}{l}21 \\
25.0\end{array}$ & $\begin{array}{l}51 \\
51.3\end{array}$ & $\begin{array}{l}8.5 \\
7.3\end{array}$ \\
\hline CHDD & Pool & $\begin{array}{l}\text { Observed } \\
\text { Expected } \\
\text { E/O ratio }\end{array}$ & $\begin{array}{l}227 \\
226.8 \\
1.00\end{array}$ & $\begin{array}{l}8 \\
9.6\end{array}$ & $\begin{array}{l}29 \\
18.5\end{array}$ & $\begin{array}{l}22 \\
29.1\end{array}$ & $\begin{array}{l}38 \\
48.5\end{array}$ & $\begin{array}{l}130 \\
121.1\end{array}$ & $\begin{array}{l}16.2 \\
12.6\end{array}$ \\
\hline $\mathrm{CHDH}$ & $\mathrm{NE}$ & $\begin{array}{l}\text { Observed } \\
\text { Expected } \\
\text { E/O ratio }\end{array}$ & $\begin{array}{l}190 \\
190.5 \\
1.00\end{array}$ & $\begin{array}{l}12 \\
12.1\end{array}$ & $\begin{array}{l}14 \\
20.9\end{array}$ & $\begin{array}{l}29 \\
30.0\end{array}$ & $\begin{array}{l}55 \\
43.4\end{array}$ & $\begin{array}{l}80 \\
84.1\end{array}$ & $\begin{array}{l}6.7 \\
6.9\end{array}$ \\
\hline $\mathrm{CHDH}$ & SE & $\begin{array}{l}\text { Observed } \\
\text { Expected } \\
\text { E/O ratio }\end{array}$ & $\begin{array}{l}192 \\
192.1 \\
1.00\end{array}$ & $\begin{array}{l}12 \\
14.6\end{array}$ & $\begin{array}{l}26 \\
23.6\end{array}$ & $\begin{array}{l}32 \\
32.3\end{array}$ & $\begin{array}{l}44 \\
44.0\end{array}$ & $\begin{array}{l}78 \\
77.6\end{array}$ & $\begin{array}{l}6.5 \\
5.3\end{array}$ \\
\hline $\mathrm{CHDH}$ & Pool & $\begin{array}{l}\text { Observed } \\
\text { Expected } \\
\text { E/O ratio }\end{array}$ & $\begin{array}{l}382 \\
383.7 \\
1.00\end{array}$ & $\begin{array}{l}19 \\
20.1\end{array}$ & $\begin{array}{l}51 \\
36.2\end{array}$ & $\begin{array}{l}46 \\
54.4\end{array}$ & $\begin{array}{l}74 \\
85.9\end{array}$ & $\begin{array}{l}192 \\
187.1\end{array}$ & $\begin{array}{l}10.1 \\
9.3\end{array}$ \\
\hline CHDA & NE & $\begin{array}{l}\text { Observed } \\
\text { Expected } \\
\text { E/O ratio }\end{array}$ & $\begin{array}{l}391 \\
391.1 \\
1.00\end{array}$ & $\begin{array}{l}38 \\
36.3\end{array}$ & $\begin{array}{l}44 \\
54.3\end{array}$ & $\begin{array}{l}75 \\
70.2\end{array}$ & $\begin{array}{l}92 \\
90.1\end{array}$ & $\begin{array}{l}142 \\
140.2\end{array}$ & $\begin{array}{l}3.7 \\
3.9\end{array}$ \\
\hline CHDA & SE & $\begin{array}{l}\text { Observed } \\
\text { Expected } \\
\text { E/O ratio }\end{array}$ & $\begin{array}{l}395 \\
394.6 \\
1.00\end{array}$ & $\begin{array}{l}35 \\
37.4\end{array}$ & $\begin{array}{l}51 \\
53.6\end{array}$ & $\begin{array}{l}85 \\
68.4\end{array}$ & $\begin{array}{l}78 \\
88.6\end{array}$ & $\begin{array}{l}146 \\
146.6\end{array}$ & $\begin{array}{l}4.2 \\
3.9\end{array}$ \\
\hline CHDA & Pool & $\begin{array}{l}\text { Observed } \\
\text { Expected } \\
\text { E/O ratio }\end{array}$ & $\begin{array}{l}786 \\
785.3 \\
1.00\end{array}$ & $\begin{array}{l}49 \\
52.8\end{array}$ & $\begin{array}{l}100 \\
82.3\end{array}$ & $\begin{array}{l}112 \\
118.6\end{array}$ & $\begin{array}{l}164 \\
181.8\end{array}$ & $\begin{array}{l}361 \\
349.8\end{array}$ & $\begin{array}{l}7.4 \\
6.6\end{array}$ \\
\hline
\end{tabular}

E/O ratio, ratio expected cases/observed cases; RR 5/1, relative risk quintile 5 over quintile 1 ; see tables 1 and 2 for key to other abbreviations.

CROSSOVER OF MULTIVARIATE MODELS BETWEEN DIFFERENT AREAS

The data are given in table 4 . The overall number of expected cases was different from the overall number of observed cases. The expected to observed ratio was more than 1 when the northern European models were applied to the southern European cohorts (ratios of 1.5 or more); and less than 1 when the southern European models were applied to the northern European cohorts (ratios around $0.5)$. However, the relative risks between cases in quintile 5 and cases in quintile 1 of the estimated risk distributions were comparable to those obtained when applying back the models to their own populations.

When the observed cases were distributed for the two end points not generating the specific solution, high levels of relative risk were again shown for cases belonging to a different end point and predicted by a different model (data not reported in detail).

RISK CHARTS

Risk charts were constructed separately for northern and southern Europe, with estimated probabilities for the occurrence of CHDD, $\mathrm{CHDH}$, and CHDA events over 10 years. They were based on three ages (40,50, and 60 years), smoking habit (no, yes), four levels of systolic blood pressure (120, 140, 160, and $180 \mathrm{~mm} \mathrm{Hg}$ ), and five levels of total serum cholesterol $(4,5,6,7$, and $8 \mathrm{mmol} / \mathrm{l})$. For brevity, only the risk charts for $\mathrm{CHDH}$ are reported in detail (tables 5 and 6), as in clinical practice coronary heart disease defined by hard criteria

Table 4 Back application of coefficients to the opposite population

\begin{tabular}{|c|c|c|c|c|c|c|c|c|c|}
\hline \multirow[b]{2}{*}{ CHD type } & \multirow[b]{2}{*}{ Area } & & \multirow{2}{*}{$\begin{array}{l}\text { Total } \\
\text { cases }\end{array}$} & \multicolumn{5}{|c|}{ Quintile class } & \multirow[b]{2}{*}{ RR $5 / 1$} \\
\hline & & & & 1 & 2 & 3 & 4 & 5 & \\
\hline CHDD & $\begin{array}{l}\text { Coefficients of NE } \\
\text { applied to SE }\end{array}$ & $\begin{array}{l}\text { Observed } \\
\text { Expected } \\
\text { E/O ratio }\end{array}$ & $\begin{array}{l}113 \\
166.2 \\
1.47\end{array}$ & $\begin{array}{l}5 \\
7.6\end{array}$ & $\begin{array}{l}5 \\
14.5\end{array}$ & $\begin{array}{l}16 \\
22.4\end{array}$ & $\begin{array}{l}34 \\
35.1\end{array}$ & $\begin{array}{l}54 \\
86.6\end{array}$ & $\begin{array}{l}10.2 \\
11.4\end{array}$ \\
\hline CHDD & $\begin{array}{l}\text { Coefficients of SE } \\
\text { applied to NE }\end{array}$ & $\begin{array}{l}\text { Observed } \\
\text { Expected } \\
\text { E/O ratio }\end{array}$ & $\begin{array}{l}114 \\
70.0 \\
0.61\end{array}$ & $\begin{array}{l}4 \\
4.6\end{array}$ & $\begin{array}{l}6 \\
7.8\end{array}$ & $\begin{array}{l}17 \\
10.9\end{array}$ & $\begin{array}{l}31 \\
15.6\end{array}$ & $\begin{array}{l}56 \\
31.1\end{array}$ & $\begin{array}{l}14.0 \\
6.7\end{array}$ \\
\hline $\mathrm{CHDH}$ & $\begin{array}{l}\text { Coefficients of NE } \\
\text { applied to SE }\end{array}$ & $\begin{array}{l}\text { Observed } \\
\text { Expected } \\
\text { E/O ratio }\end{array}$ & $\begin{array}{l}192 \\
316.6 \\
1.65\end{array}$ & $\begin{array}{l}13 \\
18.4\end{array}$ & $\begin{array}{l}26 \\
32.7\end{array}$ & $\begin{array}{l}39 \\
47.9\end{array}$ & $\begin{array}{l}38 \\
71.1\end{array}$ & $\begin{array}{l}76 \\
146.5\end{array}$ & $\begin{array}{l}5.8 \\
8.0\end{array}$ \\
\hline $\mathrm{CHDH}$ & $\begin{array}{l}\text { Coefficients of SE } \\
\text { applied to NE }\end{array}$ & $\begin{array}{l}\text { Observed } \\
\text { Expected } \\
\text { E/O ratio }\end{array}$ & $\begin{array}{l}190 \\
113.4 \\
0.60\end{array}$ & $\begin{array}{l}11 \\
9.0\end{array}$ & $\begin{array}{l}12 \\
14.3\end{array}$ & $\begin{array}{l}34 \\
19.3\end{array}$ & $\begin{array}{l}55 \\
26.1\end{array}$ & $\begin{array}{l}78 \\
44.7\end{array}$ & $\begin{array}{l}7.1 \\
4.9\end{array}$ \\
\hline CHDA & $\begin{array}{l}\text { Coefficients of NE } \\
\text { applied to SE }\end{array}$ & $\begin{array}{l}\text { Observed } \\
\text { Expected } \\
\text { E/O ratio }\end{array}$ & $\begin{array}{l}395 \\
703.5 \\
1.78\end{array}$ & $\begin{array}{l}36 \\
60.5\end{array}$ & $\begin{array}{l}52 \\
95.6\end{array}$ & $\begin{array}{l}86 \\
122.3\end{array}$ & $\begin{array}{l}74 \\
162.2\end{array}$ & $\begin{array}{l}147 \\
265.9\end{array}$ & $\begin{array}{l}4.1 \\
4.4\end{array}$ \\
\hline CHDA & $\begin{array}{l}\text { Coefficients of SE } \\
\text { applied to NE }\end{array}$ & $\begin{array}{l}\text { Observed } \\
\text { Expected } \\
\text { E/O ratio }\end{array}$ & $\begin{array}{l}391 \\
201.0 \\
0.51\end{array}$ & $\begin{array}{l}40 \\
20.0\end{array}$ & $\begin{array}{l}48 \\
28.2\end{array}$ & $\begin{array}{l}67 \\
35.3\end{array}$ & $\begin{array}{l}96 \\
45.1\end{array}$ & $\begin{array}{l}140 \\
72.4\end{array}$ & $\begin{array}{l}3.5 \\
3.6\end{array}$ \\
\hline
\end{tabular}


Table 5 Risk of hard coronary events (CHDH) per 1000 over 10 years in male subjects aged 40, 50, and 60 years, estimated by the model for northern Europe

\begin{tabular}{|c|c|c|c|c|c|c|c|c|c|c|c|}
\hline \multicolumn{6}{|c|}{ Non-smokers } & \multicolumn{6}{|c|}{ Smokers } \\
\hline \multirow[b]{2}{*}{$S B P$} & \multicolumn{5}{|c|}{ Cholesterol } & \multirow[b]{2}{*}{$S B P$} & \multicolumn{5}{|c|}{ Cholesterol } \\
\hline & 4 & 5 & 6 & 7 & 8 & & 4 & 5 & 6 & 7 & 8 \\
\hline \multicolumn{12}{|c|}{ Age 60 years } \\
\hline 180 & 132 & 166 & 205 & 252 & 305 & 180 & 193 & 237 & 288 & 345 & 407 \\
\hline 160 & 88 & 112 & 141 & 176 & 218 & 160 & 132 & 165 & 204 & 251 & 304 \\
\hline 140 & 58 & 74 & 94 & 119 & 150 & 140 & 88 & 111 & 140 & 175 & 217 \\
\hline 120 & 37 & 48 & 62 & 79 & 101 & 120 & 57 & 73 & 94 & 119 & 149 \\
\hline \multicolumn{12}{|c|}{ Age 50 years } \\
\hline 180 & 68 & 86 & 110 & 138 & 173 & 180 & 102 & 129 & 162 & 201 & 247 \\
\hline 160 & 44 & 57 & 72 & 92 & 117 & 160 & 67 & 86 & 109 & 138 & 172 \\
\hline 140 & 28 & 37 & 47 & 61 & 78 & 140 & 44 & 56 & 72 & 92 & 116 \\
\hline 120 & 18 & 24 & 30 & 39 & 51 & 120 & 28 & 36 & 47 & 60 & 77 \\
\hline \multicolumn{12}{|c|}{ Age 40 years } \\
\hline 180 & 33 & 43 & 55 & 71 & 91 & 180 & 51 & 66 & 84 & 107 & 135 \\
\hline 160 & 21 & 28 & 36 & 46 & 59 & 160 & 33 & 43 & 55 & 71 & 90 \\
\hline 140 & 14 & 18 & 23 & 30 & 39 & 140 & 21 & 28 & 36 & 46 & 59 \\
\hline 120 & 9 & 11 & 15 & 19 & 25 & 120 & 14 & 18 & 23 & 30 & 38 \\
\hline
\end{tabular}

Cholesterol in $\mathrm{mmol} / \mathrm{l}$; SBP, systolic blood pressure in $\mathrm{mm} \mathrm{Hg}$.

corresponds to the most common notion of the coronary heart disease event. The same data were converted into a colour chart (fig 1) using the same format as in a European Task Force report. $^{2}$ As expected, the probabilities are systematically greater for northern Europeans than for southern Europeans, everything else being equal. Of 120 cells in each chart, those with probabilities greater than $100 / 1000$ in 10 years $(10 \%)$ are, for CHDD, 20 in northern Europe and 5 in southern Europe; for $\mathrm{CHDH}$, 43 in northern Europe and 15 in southern Europe; and for CHDA, 92 in northern Europe and 49 in southern Europe. All else being equal, the ratios of northern to southern European exact risk (adjusted for age and smoking) ranged on average between 1.32 and 1.50 for CHDD, between 1.43 and 1.96 for $\mathrm{CHDH}$, and between 1.68 and 1.95 for CHDA.

The chart shows a large difference in the effect of age. For example, a northern European non-smoking man with cholesterol of $5 \mathrm{mmol} / \mathrm{l}$ and a systolic blood pressure of $120 \mathrm{~mm} \mathrm{Hg}$ has a risk of $11 / 1000$ at age 40 and of $48 / 1000$ at age 60 . For a smoker in the same area, these rates are $18 / 1000$ and $73 / 1000$, respectively. This implies an increase by a factor of 4. For a southern European man the

Table 6 Risk of hard coronary events $(\mathrm{CHDH})$ per 1000 in 10 years in male subjects aged 40, 50, and 60 years estimated by the model for southern Europe

\begin{tabular}{|c|c|c|c|c|c|c|c|c|c|c|c|}
\hline \multicolumn{6}{|c|}{ Non-smokers } & \multicolumn{6}{|c|}{ Smokers } \\
\hline \multirow[b]{2}{*}{$S B P$} & \multicolumn{5}{|c|}{ Cholesterol } & \multirow[b]{2}{*}{$S B P$} & \multicolumn{5}{|c|}{ Cholesterol } \\
\hline & 4 & 5 & 6 & 7 & 8 & & 4 & 5 & 6 & 7 & 8 \\
\hline \multicolumn{12}{|c|}{ Age 60 years } \\
\hline 180 & 55 & 70 & 89 & 112 & 140 & 180 & 87 & 110 & 137 & 171 & 210 \\
\hline 160 & 42 & 53 & 67 & 85 & 108 & 160 & 66 & 84 & 106 & 133 & 165 \\
\hline 140 & 31 & 40 & 51 & 65 & 82 & 140 & 50 & 64 & 81 & 102 & 128 \\
\hline 120 & 23 & 30 & 38 & 49 & 62 & 120 & 38 & 48 & 61 & 78 & 98 \\
\hline \multicolumn{12}{|c|}{ Age 50 years } \\
\hline 180 & 32 & 41 & 52 & 66 & 84 & 180 & 51 & 65 & 82 & 104 & 130 \\
\hline 160 & 24 & 31 & 39 & 50 & 64 & 160 & 38 & 49 & 62 & 79 & 100 \\
\hline 140 & 18 & 23 & 29 & 38 & 48 & 140 & 29 & 37 & 47 & 60 & 76 \\
\hline 120 & 13 & 17 & 22 & 28 & 36 & 120 & 21 & 27 & 35 & 45 & 58 \\
\hline \multicolumn{12}{|c|}{ Age 40 years } \\
\hline 180 & 18 & 23 & 30 & 38 & 49 & 180 & 29 & 36 & 48 & 61 & 77 \\
\hline 160 & 13 & 17 & 22 & 29 & 37 & 160 & 22 & 28 & 36 & 46 & 59 \\
\hline 140 & 10 & 13 & 17 & 21 & 28 & 140 & 16 & 21 & 27 & 35 & 44 \\
\hline 120 & 7 & 10 & 12 & 16 & 21 & 120 & 12 & 16 & 20 & 26 & 33 \\
\hline
\end{tabular}

Cholesterol in $\mathrm{mmol} / 1$; SBP, systolic blood pressure in $\mathrm{mm} \mathrm{Hg}$. increase is from 10 to $30 / 1000$ for a nonsmoker and from 16 to $48 / 1000$ for a smoker, or a factor of 3. Again, in northern European at age 40 the difference between a non-smoker with a cholesterol of $5 \mathrm{mmol} / \mathrm{l}$ and a systolic blood pressure of $120 \mathrm{~mm} \mathrm{Hg}$ compared with a smoker with a cholesterol of $8 \mathrm{mmol} / \mathrm{l}$ and a systolic blood pressure of $180 \mathrm{~mm} \mathrm{Hg}$ is $11 / 1000 v 135 / 1000$, or a 12 -fold increase. At age 60, this difference becomes 48/1000 $v 407 /$ 1000 , or an eightfold increase. For southern Europe these figures are, at age 40,10/1000 v $77 / 1000$ or an eightfold increase, and at age 60 , $30 / 1000 v 210 / 1000$ or a sevenfold increase.

\section{Discussion}

The 10 year incidence rates of coronary heart disease events in northern European cohorts from the seven countries study are much greater than in the southern Europe cohorts. However, these rates are slightly overestimated in both areas, as deaths from causes other than coronary heart disease were omitted from the denominator for reasons given above.

Risk functions based on multiple logistic function produce coefficients that are not significantly different between the northern and the southern European cohorts in this study. The coefficients are larger for the more severe manifestations of the disease.

The discrimination between cases and noncases, expressed by the relative risk of the observed cases in quintile $5 v$ the observed cases in quintile 1 of the estimated probabilities, is good in both northern and southern Europe, and similar in magnitude. These relative risks are larger for more severe manifestations of the disease.

The discrimination is equally good when the risk functions are applied to a different population (that is, northern European coefficients applied to southern European cohorts and vice versa), confirming that the relation of risk factors to events has a similar strength in the two cultures. The discrimination is particularly good when the European pooled solution was tested and the coefficient of the dummy variable identifying areas (north and south) was also applied.

On the other hand, the absolute risk is still different, as the number of observed events is overestimated when the northern European models are applied to the southern European cohorts (ratio of about 1.5). The opposite occurs and the number of events is underestimated when the southern European models are applied to the northern European cohorts (ratio of about 0.5).

As the coefficients for the four chosen risk factors are not significantly different between the two cultures, the pooled solutions were also produced, including dummy variables for the identification of areas. The exponential of the coefficients of the dummy variables suggests that the incidence in southern Europe compared with northern Europe, all else being equal, should be about $62 \%$ for CHDD, $57 \%$ for $\mathrm{CHDH}$, and $48 \%$ for CHDA. This suggests that the incidence in southern Europe is about $50 \%$ lower than in northern Europe, with some 
Northern Europe

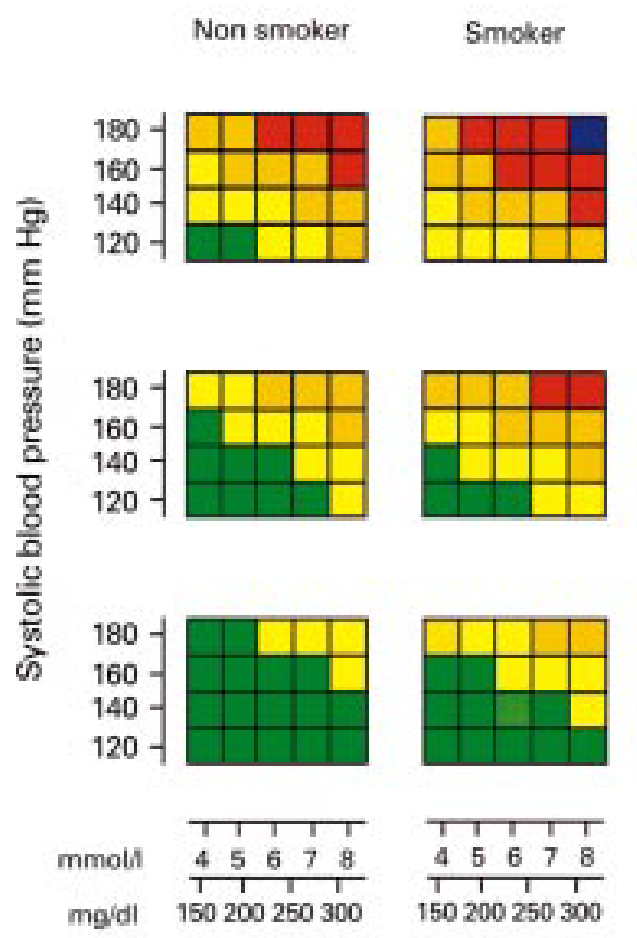

Southern Europe

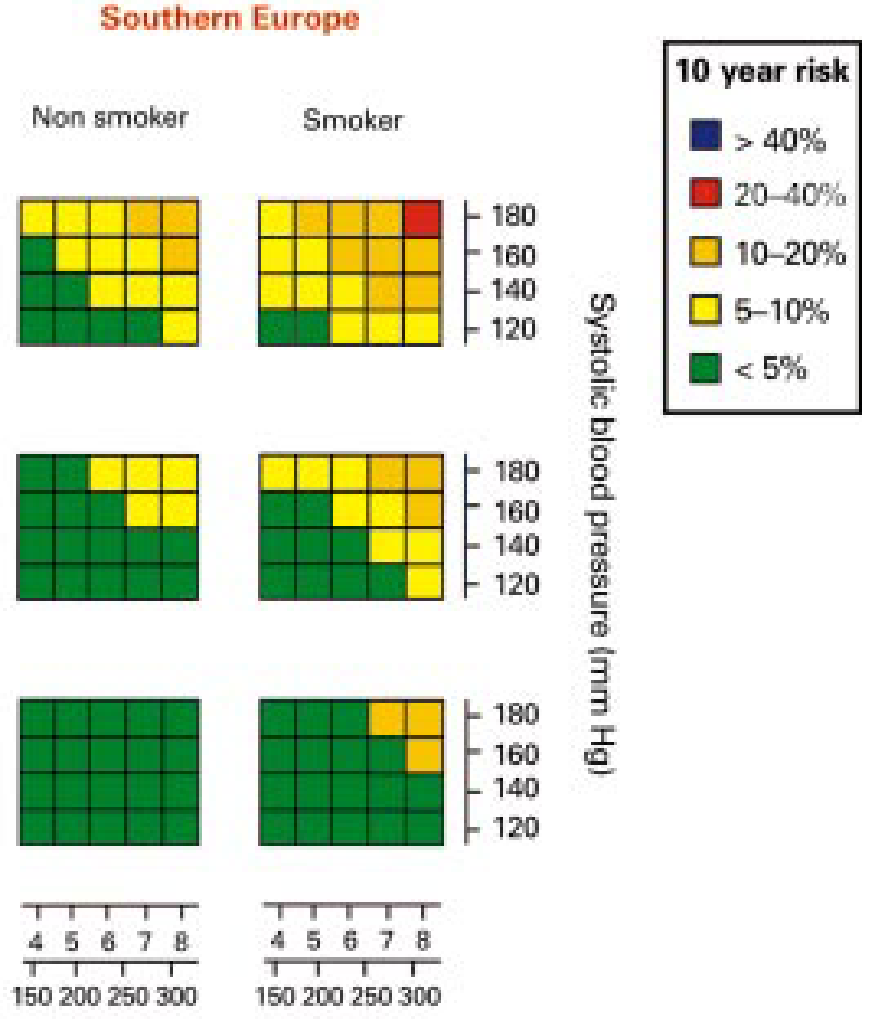

\section{Cholesterol}

Age 60

Age 50

Age 40

\section{Cholesterol}

Figure 1 Risk chart for the prediction of hard criteria coronary heart disease incidence, derived from the data in tables 5 and 6.

variation depending on coronary heart disease manifestation. This also means that the remaining difference of the original incidence ratio (2.65 minus 0.5 ) should be attributed to the different levels of the risk factors considered.

The risk charts show once again that for the same levels of risk factors, the estimated incidence of coronary heart disease in southern Europe is systematically lower than in northern Europe. The larger effect of age in the northern than in the southern European cohorts might reflect a longer exposure to higher risk factor levels.

In the southern European area, our analysis included some cohorts belonging to former Yugoslavia, where at present coronary heart disease incidence - or at least coronary heart disease mortality - is higher than in the remainder of southern Europe, in line with the trend recently manifested by the other eastern European countries. ${ }^{12} 13$ However, the incidence data reported here refer to the 1960s, when the explosion in coronary heart disease incidence and mortality in the eastern European countries had not yet become evident. In fact the incidence rates in these cohorts from the former Yugoslavia were of the same magnitude or smaller than those reported for the Italian cohorts. ${ }^{78}$ On the other hand, during the 1970 s and the 1980s an excess increase in coronary heart disease mortality was seen in these Yugoslavian cohorts, mainly the Serbian ones. ${ }^{14}$

Most of the findings reported here are already known. For example, the overestima- tion and underestimation of incidence found when crossing different risk functions with different populations was shown in early multivariate analyses of the seven countries data, ${ }^{815}$ while the notion of similarities in multivariate coefficients was documented in later analyses. ${ }^{16}$ However, the current analysis is systematic and focuses on the practical use of risk functions in coronary risk appraisal.

In conclusion this exercise suggests the following:

- the production of a single European risk chart for coronary heart disease is problematical, owing to the different incidence in different cultures;

- the coefficients for basic risk factors are of the same magnitude in northern and southern Europe;

- if a reasonable correction factor is identified and applied, relatively accurate estimates of risk probabilities can be made using the same models in different cultures;

- the relative proportions of different manifestations of coronary heart disease incidence are similar in northern and southern Europe, suggesting the possibility of creating and applying another coefficient to convert mortality estimates into incidence estimates;

- the incidence ratios between northern and southern Europe are around 2.65; when the same levels of risk factors are chosen, this ratio declines to about 1.5 , which represents the ratio not explained by these risk factors; therefore, a coefficient derived from these figure could be used to adjust the estimates of the absolute risk. 
The concepts expressed here, using more recent incidence and mortality data, could be exploited for the construction of a European coronary risk chart offering an adjustment in relation to different end points and different countries and cultures.

This work was partly funded by the Martenson Foundation Wayzata, Minnesota, USA, and by a personal grant to AM from the Associazione per la Ricerca Cardiologica (Association for Cardiac Research), Rome, Italy. We thank Prof Henry Blackburn, University of Minnesota, for reviewing the manuscript. We also acknowledge the contribution of the original principal investigators of the seven countries study in organising the study and collecting data: Professor A Keys and Professor $\mathrm{H}$ Blackburn, Minneapolis, USA; Professor M J Karvonen and D $S$ Punsar, Helsinki, Finland; Professor F Fidanza, Perugia, Italy; Professor R Buzina and Professor I Mohacek, Zagreb, Croatia; Professor $\mathrm{R}$ Buzina an; Proser Professor S Nedelikovic, Belgrade, Serbia-Yugoslavia; Professor H Toshima, Kurume, Japan.

1 Prevention of coronary heart disease in clinical practice. Recommendations of the Task Force of the European Society of Cardiology, European Atherosclerosis Society and European Society of Hypertension. Eur Heart $\mathcal{f}$ 1994;15:1300-31.

2 Prevention of coronary heart disease in clinical practice. Recommendations of the Second Joint Task Force of European and other Societies on coronary prevention. Eur Heart pean and other Societies

f 1998;19:1434-503.

3 Multiple authors. Cardiology 1993;82:issues 2-3.

4 Anderson KM, Wilson PWF, Odell PM, et al. An updated coronary risk profile. A statement for health professionals. Circulation 1991;83:356-62.
5 Menotti A, Puddu PE, Lanti M. Comparison of the FramMenotti A, Puddu PE, Lanti M. Comparison of the Framngham risk function-based coronary chart with a risk function from an

$2000 ; 21: 365-70$.
6 Keys A, Blackburn HW, Van Buchem FSP, et al. Epidemiological studies related to coronary heart disease: characteristics of men aged 40-59 in seven countries. Acta Med Scand 1967;469(suppl 180):1-392.

7 Keys A, Blackburn H, Menotti A, et al. Coronary heart disease in seven countries. Circulation 1970;41(suppl 1):1211.

8 Keys A, Aravanis C, Blackburn H, et al. Seven countries study. A multivariate analysis of death and coronary heart disease.

9 World Health Organisation. International classification of diseases, 8th revision. Geneva: WHO, 1975.

10 Rose GA, Blackburn H. Cardiovascular survey methods. Geneva: WHO, 1968.

11 Anderson JT, Keys A. Cholesterol in serum and lipoprotein fractions: its measurement and stability. Clin Chem 1956;2: 45-159.

12 Uemura K, Pisa Z. Trends in cardiovascular disease mortality in industrialised countries since 1950. World Health Stat $Q$ 1988;41:155-78.

13 WHO MONICA project. Myocardial infarction and coronary deaths in the World Health Organisation MONICA Project. Circulation 1994;90:583-612.

14 Menotti A, Keys A, Kromhout D, et al. Inter-cohort differences in coronary heart disease mortality in the 25 -year follow-up of the Seven Countries Study. Eur $f$ Epidemiol 1993;9:527-36.

15 Keys A, Aravanis C, Blackburn H, et al. Probability of middle aged men developing coronary heart disease in five

16 Menotti A, Keys A, Blackburn H. Comparison of multivariate predictive power of major risk factors for coronary heart disease in different countries: results from eight nations of the Seven Countries Study, 25-year follow-up. 7 Cardiovasc Risk 1996;3:69-75.

\section{IMAGES IN CARDIOLOGY}

\section{Double orifice mitral valve}

Double orifice mitral valve (DOMV) is a rare congenital anomaly of the subvalvar mitral valve apparatus (chordae tendinae and papillary muscles) consisting of an accessory bridge of fibrous tissue, which partially or completely divides the mitral valve into two orifices. The size of the orifices is balanced in only $15 \%$. Anatomically and functionally, the mitral leaflets are essentially normal in most cases, but they can be regurgitant or stenotic. DOMV rarely occurs as an isolated anomaly, but is most commonly associated with a variety of other cardiac anomalies such as atrioventricular septal defects, coarctation of the aorta, bicuspid aortic valve, sinus venosus atrial septal defect, ventricular septal defect, patent ductus arteriosus, hypoplastic left heart syndrome, double orifice tricuspid valve, tetralogy of Fallot, and Ebstein's anomaly. Acquired DOMV may be present after surgical correction of a mitral valve prolapse where the free edge of the middle portion of the prolapsing anterior or posterior leaflet is anchored to the facing edge of the opposite leaflet ("edge to edge" or "double orifice repair" technique described by Alfieri).

We describe the echocardiographic finding of a 19 year old woman with "multiple left heart obstructions" (Shone's complex) and surgically corrected ventricular septal defect and coarctation of the aorta, who was admitted for treatment of recoarctation. Echocardiography at admission surprisingly revealed a previously

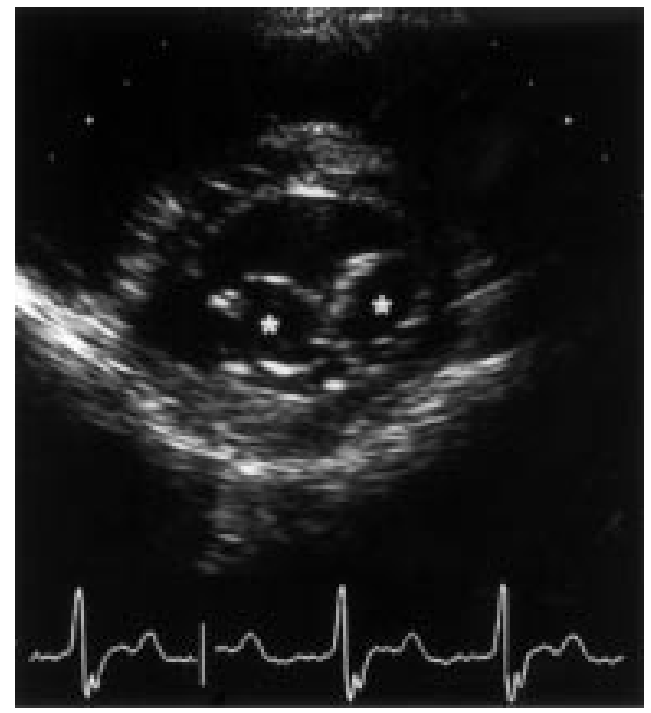

undiagnosed balanced type DOMV without significant obstruction or insufficiency. The figure shows a short view of a diastolic frame at the level of the mitral leaflet tips (asterisks indicate DOMV).

This case shows that DOMV may also exist with Shone's complex.

ANDRE Z LINKA

RENATA FATIO

CHRISTINE ATTENHOFER JOST 